\title{
Dossiê
}

\section{O discurso populista e a representação do povo no Jornal Luta Democrática}

\author{
The populist discourse and the representation of the \\ people on the Luta Democrática newspaper
}

\author{
Claudio Araujo de Souza e Silva \\ Professor, Universidade Federal Fluminense (UFF), Campos dos \\ Goytacazes, RJ, Brasil \\ claudiosouzaesilva@gmail.com
}

\begin{abstract}
Resumo: Este artigo analisa de que maneira o jornal Luta Democrática construiu um canal de conexão entre o político Tenório Cavalcanti, dono do periódico, e as suas bases eleitorais. O objetivo é mostrar como a abordagem sobre o discurso utilizado por este jornal popular pode dialogar com o conceito de populismo desenvolvido pelo teórico político argentino Ernesto Laclau. A pesquisa foi realizada entre o ano da fundação do jornal - 1954 - e o fim da experiência democrática da República de 46, demarcado pelo golpe militar de 1964. A análise se concentrou em manchetes, reportagens, seções do periódico destinadas para as queixas dos leitores e nas ideias expressas por alguns de seus colunistas sobre problemas e demandas sociais. Assim, concluo que a forma como o Luta Democrática buscava se comunicar com o seu público leitor era parte integrante da imagem pública construída em torno deste político e, sobretudo, que essa interação teve como resultado a invenção de mecanismos de representação, noções de pertencimento, identidade coletiva e inclusão social. Esses elementos ajudam a entender o papel de uma liderança popular no processo de incorporação política da população e, consequentemente, evidenciam algumas formas de expressão da cidadania brasileira que se consolidava na época.
\end{abstract}

Palavras-chave: Populismo; Imprensa popular; Luta Democrática; Tenório Cavalcanti.

\footnotetext{
Abstract: This article analyzes how the newspaper Luta Democrática connected its owner, the politician Tenório Cavalcanti, with his voters. The aim is to demonstrate how the discourse of this popular press outlet is related with the concept of populism developed by Ernesto Laclau. I analyzed the newspaper from 1954 - the year in which the paper was founded - until 1964,
} 
which marks the end of the democratic period in Brazil. I searched for headlines, reports and articles containing reader's comments, as well as editorial articles about social problems. The paper conclude that the way in which the newspaper communicated with its readership was an integral part of how this politician's public image was built and, above all, that this interaction resulted in the invention of mechanisms of political representation, notions of belonging, collective identity and social inclusion. These elements help us to understand the role of Brazilian popular politician in including citizens in the political process in the country.

Keywords: Populism; Popular press; Luta Democrática; Tenório Cavalcanti.

\section{Os deslizamentos do populismo}

Populismo é um termo extremamente carregado de significados e, por isso, complexo. É até mesmo difícil defini-lo propriamente como um conceito, dada a imprecisão de seus usos - e abusos - para caracterizar os fenômenos históricos de natureza política. Em todo caso, é palavra presente no imaginário político da população brasileira, sobretudo, a partir dos anos 1950. Ao longo dessa trajetória, de tempos em tempos, assim como o pássaro Fênix, a expressão resurge das cinzas e, após períodos de ostracismo, volta a balizar o tom dos debates políticos. Agoniza mas não morre, como a trajetória do samba cantada na letra de Nelson Sargento'.

O objetivo deste artigo é apresentar uma leitura alternativa sobre o populismo com base em uma pesquisa empírica realizada no jornal Luta Democrática², que pertencia ao político Tenório Cavalcanti. Conhecido como "Rei da Baixada" ou "O Homem da Capa Preta", Tenório Cavalcanti foi um político popular que atuou fundamentalmente em regiões pobres e periféricas da cidade e do estado do Rio de Janeiro entre as décadas de 1930 e 1960. O seu nicho eleitoral era na região da Baixada Fluminense, mais especificamente, no município de Duque de Caxias. Resumidamente, a sua trajetória política se iniciou quando ele foi eleito vereador por Nova Iguaçu em 1936 (na época, Duque de Caxias era distrito de Nova Iguaçu). Em 1947, foi eleito deputado estadual pelo estado do Rio de Janeiro; posteriormente elegeu-se deputado federal por quatro vezes consecutivas (1950, 54, 58 e 62). Além disso, foi candidato ao governo do estado da Guanabara, em 1960 e candidato ao governo do estado do Rio de Janeiro, em 1962.

1 A música intitulada "Agoniza mas não morre" compõe o LP "Sonho de um sambista", gravado em 1979.

2 A pesquisa foi realizada no acervo de periódicos da Biblioteca Nacional. 
A imprensa desempenhou um importante papel na vida política nacional no período democrático construído entre 1945 e 1964. A redemocratização do país trouxe a volta da concorrência eleitoral entre os partidos políticos. A obrigatoriedade do voto para a população alfabetizada e maior de 18 anos, estabelecida na Constituição de 1946, levou os partidos de todas as correntes a buscarem o apoio popular. Com a classe política sendo escolhida por um eleitorado maior ${ }^{3}$, os jornais se tornaram peça fundamental para a formação da opinião pública e para a construção de partidos e lideranças políticas de massa. Criado em fevereiro de 1954, o jornal Luta Democrática teve papel decisivo na consolidação das bases eleitorais de Tenório Cavalcanti. Para isso o jornal utilizou uma linguagem sensacionalista e divulgou diversos tipos de demandas populares e de expressão da cidadania durante a República de 46. Nas eleições de outubro de 1954, o parlamentar fluminense ampliou a sua votação em quase 33 mil votos em relação a $1950^{4}$ e, desse modo, se tornou o deputado federal mais votado do estado do Rio de Janeiro naquele pleito, fato que se repetiu nas eleições de 1958. Somente após a criação do periódico, o político da Baixada teve capacidade de se conectar com amplos segmentos sociais e se tornar conhecido nacionalmente. As manchetes, reportagens, seções e colunas do jornal serviram como um espaço de mediação entre Tenório Cavalcanti e a população.

De forte tradição no Rio de Janeiro, a imprensa sensacionalista e popular veio se consolidando ao longo do século XX como um veículo de expressão de diversos segmentos sociais, especialmente os mais marginalizados. Siqueira (2002) analisa o importante papel que os jornais populares O Dia, Última Hora e o próprio Luta Democrática desempenharam durante o segundo governo Vargas (1951-1954) como intermediários entre o público e os líderes políticos aos quais estavam ligados (Adhemar de Barros/Chagas Freitas, Getúlio Vargas e Tenório Cavalcanti, respectivamente). A autora observa que a linguagem sensacionalista e populista utilizada por esses jornais exerceu um papel importante para que as classes populares pudessem compreender ou mesmo construir uma identidade

3 Em 1945, a taxa de comparecimento às urnas, nas eleições para a Câmara dos Deputados, ultrapassou o índice de 10\% da população total do país, chegando a mais de 15\% nas eleições de 1950. Segundo Jairo Nicolau (2004, p. 46), esse índice era suficientemente relevante para colocar o Brasil entre as chamadas democracias de massa. No entanto, basta mencionar a exclusão do voto do analfabeto (somente incorporado pela Constituição de 1988) e a cassação do PCB para compreendermos as limitações desse período democrático.

4 Nas eleições de 1950, Tenório Cavalcanti obteve apenas 9.072 sufrágios, a segunda pior votação entre todos os candidatos eleitos para compor a Câmara dos Deputados e a pior votação entre os candidatos da União Democrática Nacional (UDN), partido pelo qual se candidatou. 
coletiva capaz de explicar a sua inserção no contraditório processo da modernização brasileira através de noções de cidadania e de participação política.

Ao estabelecer um diálogo com a população marginalizada e ao criar um espaço de representação e repercussão dos acontecimentos, a linguagem utilizada pelos jornais populares foi capaz de traduzir novas demandas sociais, conferindo-Ihes sentido. Portanto, a imprensa populista e sensacionalista se tornou um canal privilegiado para a negociação de demandas referentes aos grupos sociais subalternos. Uma das marcas do populismo, relata Siqueira, era a comunicação com uma parcela ampla da população. A imprensa popular destacava variados temas voltados para diversos setores das classes mais pobres e da classe média, genericamente denominados como povo. Ao relatar o cotidiano e, sobretudo, a conexão dos direitos formalmente instituídos com as demandas apresentadas pelo público leitor, esses jornais estabeleciam uma relação de troca entre a população e as instituições políticas. O sensacionalismo, por sua vez, colocava em destaque o excepcional, aquilo que fugia ao comum, que alardeava, de forma exagerada, um momento de crise e que devia fundamentalmente apelar para as sensações e emoções. Além disso, a linguagem sensacionalista era marcada pela dramatização do cotidiano e procurava relatar uma realidade que fizesse sentido para o público leitor. A representação do popular era construída pelo tom trágico ou cômico dado à notícia, o que levava o leitor a se envolver emocionalmente com os fatos. Por fim, a narrativa dramática das notícias sensacionalistas tinha um caráter moralizador que lhe dava legitimidade perante o público leitor, pois trazia até ele a ideia de envolvimento e de autorreconhecimento. A estética da dramaticidade utilizada pelos jornais sensacionalistas transgredia a linguagem racional e séria com que tradicionalmente eram tratados os assuntos políticos, especialmente pela mídia que se dizia imparcial e objetiva. Dessa forma, os fatos políticos passavam a ser tratados como fatos dramáticos capazes de interpelar a subjetividade dos leitores. Unindo o apelo emocional a uma forma radical de defesa dos direitos, esses jornais puderam funcionar como a principal ferramenta de comunicação entre as lideranças políticas populares e o público. Assim, ajudaram a construir noções de identidade coletiva.

Durante a experiência democrática da República de 46, o termo populismo foi mudando de sentido justamente em função de seus usos pela imprensa popular e sensacionalista. Em artigo publicado numa coletânea que se propôs a discutir o populismo, 
Ferreira (2001) esclarece que o termo se inseriu na própria cultura política nacional ao se tornar comum no vocabulário político. O autor enfatiza que entre 1945 e 1964 a palavra "populismo" ou "populista" esteve presente nos meios de comunicação de massa para caracterizar a legitimidade de uma liderança popular perante a população. Para o autor, inicialmente o adjetivo populista era apenas sinônimo de popular. Mas foi durante esse mesmo período que a imprensa liberal e antivarguista difundiu amplamente a conotação pejorativa que traz o sentido da manipulação, da mentira e da demagogia. Foi esse o sentido mais emblemático do populismo nos debates políticos que se sucederam desde aquela época 5 . Sem conseguir assimilar e aceitar as manifestações públicas a favor de Vargas, a direita liberal explicou o seu prestígio pela suposta incapacidade crítica das massas, compostas por indivíduos analfabetos - em sua maioria - ignorantes, sem cultura e sem educação cívica. Portanto, a solução política para reverter a popularidade de Vargas a seu favor consistia em impedir as manifestações pela força e por sucessivas tentativas golpistas, já que, na visão dos adeptos dessa corrente liberal, não se podia mudar a curto prazo uma mentalidade política manipulada pela propaganda varguista que vinha se consolidando desde o Estado Novo.

Capelato (2013) destaca que a expressão populismo se confundia com a própria caracterização do varguismo pela imprensa liberal dos anos 1950. O grupo Diários Associados - composto por jornais, rádios (Rádio Globo, especialmente) e duas emissoras de televisão (TV Tupi do Rio e TV Tupi de São Paulo) - teve papel decisivo nessa associação entre o varguismo e o populismo. Na então capital da República, o antigetulismo foi personalizado na figura do político Carlos Lacerda. O principal mentor da União Democrática Nacional (UDN) carioca usava o jornal Tribuna da Imprensa para se colocar como protagonista na campanha contra Vargas. Desde então, o populismo vem sendo usado para se fazer uma releitura do passado com fins políticos sempre quando se quer associar alguma figura política do presente com as características pejorativas de Getúlio Vargas tal como definidas pela imprensa liberal ${ }^{6}$. Desse modo, revela a autora, o uso político do termo para desqualificar governos com altos índices de popularidade faz com que o conceito perca o seu conteúdo analítico.

5 Como lembra Jorge Chaloub (2014), o fantasma do populismo transcendeu a experiência democrática de 46 e continua sendo utilizado pelos atores políticos para exorcizar seus adversários.

6 Basicamente essas características consistem na manipulação da população através do discurso carismático e o uso da popularidade para corromper as normas e instituições democráticas. 
Cabe ressaltar, no entanto, que o simples abandono do populismo em função de seus usos destorcidos pela imprensa seria algo pouco frutífero e apenas jogaria no ostracismo essa categoria que, queira-se ou não, está entranhada na história do país. Afinal, é justamente a notoriedade do termo que justifica a importância do estudo de seus inúmeros significados. Não se deve rejeitar um conceito apenas pelo uso ambíguo que dele foi feito por atores sociais ao longo da história. Conforme explica Koselleck (1985), ao invés de abandonar um conceito em função de sua capacidade de difusão de sentidos, cabe aos pesquisadores tentar compreender os seus deslocamentos do campo conceitual para o campo social e vice-versa. Gomes (1996) atenta que é importante diferenciar e, ao mesmo tempo, estabelecer o diálogo entre a forma como o espaço acadêmico vem analisando o populismo e sua presença na cultura política nacional, insuflada fundamentalmente pelos meios de comunicação de massa. Assim, reforça a autora: "[...] o exame da categoria exige o reconhecimento da ocorrência de seu deslizamento de uma retórica sociológica erudita para uma retórica política popular" (GOMES, 1996, p. 32).

A fim de tecer essa correlação necessária, na segunda parte deste artigo farei uma leitura crítica do termo em questão a partir da interpretação do jornal Luta Democrática. Pretendo mostrar como esta fonte histórica pode ser usada para construir uma abordagem alternativa sobre o populismo. Para isso, utilizarei como ferramenta analítica algumas ideias sobre o populismo desenvolvidas pelo teórico político argentino Ernesto Laclau (2013). Este autor entendeu o populismo como uma lógica específica de construção do objeto político que se articula através de práticas discursivas ${ }^{7}$. São estas práticas discursivas que servem de base para identificar os conflitos estabelecidos entre os sujeitos históricos. O recurso às práticas discursivas é o ponto central para a concepção crítica do autor, que é contrária à ideia de que existem estruturas fixas que determinam a identidade dos atores sociais no processo histórico - ideia cara aos autores marxistas. Portanto, o populismo explicaria a formação de identidades coletivas baseadas em constantes (re) construções discursivas sobre o político. Assim, segundo Laclau, a lógica populista é definida pelo discurso de construção do "povo" contra o seu inimigo, ou seja, é uma lógica que se constrói através do antagonismo. Sendo que o "povo"não é uma categoria estática, mas sim formada por uma relação aparentemente contraditória entre diversas

7 Laclau entende que as práticas discursivas articulam dimensões linguísticas e não linguísticas. 
demandas sociais particulares (a "plebs") e a representação que visa construir uma ideia

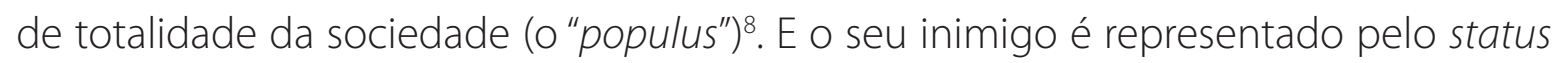
quo, consubstanciado no bloco de poder. A articulação do discurso popular que se constrói entre a "plebs" e o "populus" e contra o status quo, pode ser cristalizada através de um processo "catacrético", em que o nome do líder traduz a ideia de "povo", mas não o representa diretamente. Esse mecanismo de construção da identidade popular é designado por"razão populista". Voltarei a este ponto mais adiante, por enquanto o meu objetivo é realizar uma breve e obviamente incompleta revisão da literatura buscando resgatar a história do conceito de populismo no Brasil. Esta revisão servirá para adentrar na pesquisa empírica realizada no jornal Luta Democrática.

As primeiras análises sobre a incorporação das classes trabalhadores nos recém-inaugurados regimes democráticos da América Latina não foram muito otimistas. Durante os anos 1950 e início dos anos 1960, alguns intelectuais latino-americanos ${ }^{9}$ se basearam na teoria da modernização e construíram o conceito de populismo para caracterizar uma fase de transição entre o mundo subdesenvolvido e o mundo desenvolvido. O significado que esses teóricos deram ao populismo revelava claramente que o subdesenvolvimento da América Latina era marcado por uma democracia representativa bastante frágil, o que resultava na ocupação do espaço político por lideranças carismáticas seriamente afetadas por arroubos autoritários. O populismo seria, portanto, a consequência e também a causa da fragilidade e da instabilidade das instituições políticas nacionais, caracterizando um estágio pré-democrático.

No Brasil, alguns integrantes do Instituto Superior de Estudos Brasileiros (ISEB) ${ }^{10}$, seguiram as principais ideias dos teóricos da modernização para pensar o fenômeno do populismo no país. Esses autores buscavam compreender os motivos que obstaculizavam o encaixe do Brasil na nova ordem capitalista que começava a se delinear a partir de 1930, mas que ganhou força, sobretudo, após a Segunda Guerra Mundial. Nessa perspectiva, o país teria passado por um processo abrupto de modernização, deixando de ser agrário

8 O uso da palavra "povo" (entre aspas) serve para diferenciar o sentido dado por Laclau de seus diversos outros significados.

9 Refiro-me aos intelectuais vinculados a teoria da modernização, dentre os quais se destacam Gino Germani e Torcuato di Tella.

10 Inicialmente esses intelectuais faziam parte do Instituto Brasileiro de Economia, Sociologia e Política (IBESP), que mais tarde viria a se tornar o ISEB. O ISEB congregou um grupo de intelectuais com significativa produção sobre os problemas sociais e políticos brasileiros, cujo objetivo inicial era subsidiar o governo de Juscelino Kubitschek com novas ideias para o desenvolvimento nacional. 
para tornar-se urbano-industrial. Durante esse processo, as massas de trabalhadores não teriam conseguido se organizar em torno de canais institucionais apropriados, como teria ocorrido nos países desenvolvidos. Por consequência, surgiram práticas políticas consideradas como desencaixadas, não funcionais e atrasadas em relação à nova fase sócio-econômica que começava a se configurar. Assim, o populismo seria fruto de uma circunstância estrutural da sociedade brasileira.

O ensaio intitulado Que éo Ademarismo? (JAGUARIBE, 1954) ${ }^{11}$ foi pioneiro no debate sobre lideranças populares na democracia brasileira. Segundo esta análise, o populismo exercido pelo político Adhemar de Barros era parte inerente de uma nova fase de transição histórica que se caracterizava pela ausência de valores e ideologias representativas das classes sociais progressistas (os setores urbano-industriais, constituídos pela burguesia industrial, a classe média dos setores técnicos e administrativos e o proletariado urbano). Desse modo, o populismo seria um fenômeno descolado de qualquer tipo de representação institucional moderna e surgia da incapacidade das classes progressistas em se adaptarem ao processo de desenvolvimento industrial. Esse estudo descreveu os discursos e o simbolismo utilizados pelos políticos populistas como "verborragia pseudo-social" e as manifestações das massas como expressão confusa e primária. Para evitar o crescimento do fenômeno populista era necessário unir as classes sociais progressistas em torno de um projeto ideológico hegemônico, que passou a ser designado como nacional-desenvolvimentismo. Esse projeto ideológico baseava-se na concepção de que o desenvolvimento nacional englobava temas de interesse comum entre diversos setores de classe, compostos tanto pela burguesia industrial, como também pelos setores modernos da burocracia estatal e do operariado urbano ${ }^{12}$.

No fim dos anos 1960, outra corrente de intelectuais, dessa vez alocada na Universidade de São Paulo (USP) e, mais tarde, no Centro Brasileiro de Análise e Planejamento (CEBRAP), voltou a pensar a incorporação das classes trabalhadoras brasileiras utilizando o conceito de populismo. Naquele momento, a questão que incentivava os analistas era pensar os motivos que desencadearam o Golpe de $1964^{13}$. O ponto central da busca recaiu

110 artigo é de publicação coletiva do IBESP, mas foi escrito por Hélio Jaguaribe.

12 Para uma análise mais completa sobre o conceito de populismo desenvolvido por intelectuais do ISEB, ver também Ramos (1961).

13 Cabe destacar que essa nova corrente intelectual pensava a partir de uma conjuntura política completamente diversa da anterior. Este novo cenário era marcado não apenas pelo Golpe de 1964, mas também pela descrença nas forças progressistas de esquerda que vinham atuando ao longo da República de 46 e pela maior influência de novos grupos esquerdistas, inclusive marcados por novas perspectivas do movimento comunista internacional. 
sobre o papel estratégico da classe operária brasileira no contexto pré-Golpe. Essa nova geração de intelectuais identificou o Estado centralizador criado por Vargas, em 1930, como sendo o principal entrave para a construção da autonomia da classe trabalhadora. Partindo de uma perspectiva teleológica sobre o desenvolvimento do capitalismo global, esses autores queriam entender os obstáculos que impediam a formação de uma classe operária independente do Estado e capaz de se auto-organizar. Concluíram que os principais elementos que abriram o caminho para a construção do sistema populista foram a ausência de consciência ideológica de classe e a capacidade de manipulação de elites políticas ligadas ao Estado autoritário e patrimonial.

As ideias da corrente uspiana na redefinição do conceito de populismo tiveram ampla repercussão ${ }^{14}$. Dentre os seus autores merece destaque a argumentação de Francisco Weffort no ensaio intitulado O populismo na política brasileira (WEFFORT, 1978). Este autor chamou atenção para o fato de que o sistema populista representava algo mais do que um fenômeno alimentado pela falta de consciência política das massas e pela manipulação destas pelos grupos dominantes, sendo também um modo de expressão das insatisfações de diversos grupos sociais. Weffort destaca que os políticos populistas atuavam de modo muito particular, porém, em comum tiveram o interesse pela conquista do voto popular e a compreensão das aspirações populares, fundamentalmente concentradas no meio urbano. No entendimento do autor, o fenômeno populista demarcava, sobretudo, uma grande arena de negociação entre lideranças políticas e as classes populares.

Ao se pautarem pelas medidas que supostamente encontravam menor resistência e maior apoio popular, as decisões políticas das lideranças populistas acabaram por criar uma noção de reconhecimento capaz de legitimar a cidadania de diversos grupos sociais até então marginalizados. Assim, o líder populista era capaz de construir algum tipo de relação com o poder público a fim de oferecer algo que favorecesse as massas: uma lei, uma melhoria na qualidade de vida ou mesmo a esperança de dias melhores. Para Weffort a política varguista forneceu a legislação trabalhista como elemento de negociação política com as classes populares. Se por um lado, a posição de doador ou protetor colocava o líder populista acima da população ao estabelecer com ela uma

14 Para mais informações sobre o conceito de populismo construído por essa corrente de intelectuais da USP ver lanni (1968) e Rodrigues (1968). 
relação paternalista e consequentemente assimétrica, por outro, a cidadania passava a ser reconhecida ao adquirir significado e importância política.

A inovação da análise de Weffort em comparação com os estudos anteriores sobre o populismo foi interpretar as classes populares urbanas, especialmente após 1945, como sujeito histórico capaz de atuar com uma relativa liberdade em relação a uma estrutura política e econômica que vinha se consolidando desde 1930. Para o autor, os líderes populistas não eram simplesmente a expressão de uma estrutura social e de uma formação ideológica indefinidas e, tampouco, eram senhores da história capazes de manipular ao seu capricho as demandas e os anseios populares. Eles foram capazes de atender a pressões reais forjadas entre as próprias classes populares. Contudo, mesmo sem menosprezar a contribuição do pacto populista para a construção da cidadania, Weffort ainda entendia que o Estado paternalista, criado em 1930, obstruiu a visão da classe operária para os seus reais interesses e camuflou a defesa de interesses pequeno-burgueses que se beneficiavam com a proteção do regime de propriedade capitalista. Portanto, não obstante a emergência das massas como ator central no sistema político populista, principalmente após 1945, essa participação ainda não caracterizava uma autonomia de classe - questão cara aos intelectuais daquele período ${ }^{15}$.

A questão central que envolve a produção acadêmica sobre o populismo no Brasil, aqui representada pelo ISEB e pela USP/CEBRAP, é que os autores elaboraram uma espécie de sociologia da ausência. Assim, ao invés de concentrarem a sua atenção nos elementos que constituíam as relações políticas do período populista, esses autores optaram por descrever aquilo que estaria faltando em tais relações. Ao invés de tentarem descrever o mundo que estava sendo construído a partir dessas relações, buscaram descrever o mundo que não estava sendo construído em função dos obstáculos ou das deficiências das classes sociais, dos partidos políticos, da esfera pública, enfim, da modernidade brasileira incompleta. De um lado, essa modernidade era marcada pelos fantasmas do atraso, sendo estes consubstanciados em relações socioculturais fortemente arraigadas em formas passadas, como o clientelismo, o patriarcalismo e

\footnotetext{
15 Sobre a questão dos obstáculos para a construção da autonomia de classe, é importante destacar a crítica que Weffort faz à chamada política de cúpula exercida pelo Partido Comunista Brasileiro (PCB), outras agremiações de esquerda e alguns movimentos grevistas que se consolidaram entre 1945 e 1964. A crítica indica que as lideranças políticas dessas instituições e movimentos foram as responsáveis pela continuidade do pacto populista e pela consequente falta de visão da classe operária sobre os acontecimentos que acarretaram no Golpe de 1964, haja vista que a aliança com o Estado impediu o surgimento de um movimento plenamente espontâneo do operariado. Esta crítica à política de cúpula dos partidos e esquerda e movimentos grevistas também foi compartilhada por Moisés (1978).
} 
o patrimonialismo. De outro, ela era esmagada pela emergência de um Estado que incorporou a racionalidade e a burocracia impessoal de modo autoritário. Esses elementos constitutivos da modernidade brasileira teriam deixado fortes lastros na sociedade civil, a grande vítima dessas interpretações.

É interessante notar que essas primeiras construções teóricas sobre o conceito de populismo acabaram por reforçar, obviamente de modo inconsciente, aquelas narrativas retóricas sobre o populismo utilizadas pela direita liberal dos anos 1950. Nos dois casos, estava presente a ideia da manipulação de lideranças populares e da presença de um Estado autoritário e paternalista sobre uma sociedade amorfa e com pouca capacidade organizativa. O curioso é que as motivações que influenciaram essa concepção sobre o populismo eram totalmente díspares. De um lado, os grupos intelectuais, sobretudo aqueles ligados a USP/CEBRAP, que se concentravam no campo da esquerda (não a esquerda nacionalista dos anos 1950, à qual se associaram alguns intelectuais do ISEB), queriam explicar porque a classe operária brasileira não pôde realizar a sua vocação histórica revolucionária, ou seja, quais os motivos que obstaculizaram a construção de sua verdadeira identidade. De outro lado, os liberais, que se concentravam em sua maioria na UDN, estavam preocupados em deslegitimar o varguismo em prol de uma ideologia política mais aberta ao capital estrangeiro e menos protecionista. Porém, em que pese o fato destes grupos procurarem caminhos completamente distintos (até mesmo em função de suas diferentes posições institucionais), ao fim e ao cabo, compartilharam ideias comuns sobre as classes trabalhadoras no Brasil.

A partir dos anos 1990, alguns pesquisadores se dedicaram a resgatar a história do conceito de populismo a fim de encontrar outros rendimentos analíticos capazes de construir novos olhares sobre a história social das classes trabalhadoras no Brasil. Cabe destacar um grupo de historiadores formados na Universidade de Campinas (UNICAMP), do qual fizeram parte Alexandre Fortes, Antonio Luigi Negro, Fernando Teixeira da Silva, Hélio da Costa e Paulo Fontes ${ }^{16}$. Com base em um profundo e variado trabalho de pesquisa em documentos históricos, esses autores se propuseram a fazer uma reavaliação crítica sobre a história das classes trabalhadoras brasileiras a partir da conexão entre a dimensão da cultura, da esfera dos direitos e da participação social

16 Como exemplo de obras publicadas por essa nova geração de estudos que fazem uma reavaliação crítica do conceito de populismo, pode-se citar: Costa et al (1999) e Ferreira (2001). 
e política no período compreendido entre 1930 e 1964. Para isso, adotaram como principal referencial teórico as ideias do historiador inglês E.P Thompson ${ }^{17}$ e de outros historiadores marxistas britânicos. A obra de Thompson foi fundamental para redefinir o conceito de classe social, central às teses anteriores sobre o populismo. O cerne da crítica estava na tentativa de superação do discurso teleológico marxista sobre a luta de classes, que seguia a concepção de que o comportamento de classe podia ser desviante ou não em relação a um modelo previamente estabelecido pela estrutura econômica inerente ao modo de produção. Justamente por não entender as estratégias políticas da classe trabalhadora de maneira teleológica, Thompson sugeriu pensar a incorporação da cidadania às massas trabalhadoras atribuindo-lhes um papel de sujeito que age a partir de um vasto campo de possibilidades. Logo, a partir deste autor foi possível construir uma agenda de pesquisa preocupada em entender a formação de classe como um processo variado de produção de identidades sociais que não estavam atreladas ao estágio de desenvolvimento econômico.

Ao fazer uma reavaliação crítica sobre o espaço ocupado pelas classes trabalhadoras na história brasileira, essa geração de historiadores foi levada a repensar o conceito de populismo. Nesse sentido, o principal desafio colocado por essa nova agenda de pesquisas foi pensar a participação política dos trabalhadores abandonando a ideia de que seria preciso superar por completo uma etapa para que a história continuasse evoluindo. Assim, nessa nova perspectiva, os estudos atuais recusaram as propostas de análise que percebiam a manipulação e a tutela estatal dos trabalhadores após 1930 como um mero obstáculo para construção de uma identidade de classe. Por conseguinte, as identidades construídas no mundo do trabalho passaram a ser entendidas como consequência de processos empíricos de articulação e de tomadas de decisão que levam em consideração as interações, os espaços de negociações e os conflitos entre os sujeitos políticos ${ }^{18}$. Essa outra noção de identidade abriu espaço para pesquisas sobre a cultura popular, o imaginário, as ideias, as crenças, os costumes, as experiências, os códigos de afetividade, as estratégias políticas, enfim, o estudo sobre os elementos histórico-culturais constitutivos das identidades da classe trabalhadora. Para tal, foram

17 A obra de maior repercussão deste autor é intitulada "A formação da classe operária inglesa" (THOMPSON, 1987).

18 Influenciados também pela obra de John D. French (2001), alguns autores destacam que a garantia legal dos direitos trabalhistas e o seu reconhecimento público no período populista, exigia mais do que trabalhadores dóceis ou gratos em relação a um projeto político estatal. Ao contrário, essas garantias resultaram em cidadãos politicamente mais independentes e bastante ativos nos conflitos interentes à esfera pública. 
utilizados métodos baseados na história oral, na história das ideias ou das mentalidades e na história cultural.

Em linhas gerais, essa nova literatura deixou de lado uma perspectiva sobre o poder mais estrutural e funcional e adotou a concepção de que o poder é constituído por disputas travadas pelos atores sociais em relação aos recursos simbólicos e materiais distribuídos de modo desigual em diferentes contextos. Dessa forma, a compreensão sobre as relações entre o Estado e sociedade civil passou a ser narrada a partir de múltiplas perspectivas e não mais levando em consideração apenas o posicionamento dos trabalhadores em relação ao regime de propriedade. Através dessa lente, o populismo continuou a ser visto como constitutivo de um momento histórico específico, mas não mais como um obstáculo à construção da identidade da classe operária. Assim, o fenômeno pôde ser analisado como algo que construiu (e não destruiu) a(s) identidade(s) dos trabalhadores brasileiros. Estava superado o problema da ausência de agência na história da classe trabalhadora no Brasil.

Como é possível perceber, o campo da historiografia tomou para si a tarefa de repensar criticamente o populismo e sua relação com a formação das identidades das classes trabalhadoras no Brasil. O foco desses estudos vai muito além do referencial teórico de Thompson, porém, por razões de espaço, seria impossível mapear toda essa produção neste artigo ${ }^{19}$. Cabe ressaltar, no entanto, que as pesquisas se aprofundam em refletir sobre as inumeráveis possibilidades de correlacionar a questão da formação de classe com outros aspectos identitários, como gênero, raça, etnia e religião (apenas para citar alguns poucos exemplos).

Essa nova agenda de pesquisas sobre as classes trabalhadoras no período populista, que começou a ganhar força a partir dos anos 1990, trouxe uma ótima contribuição que nos faz perceber o contexto histórico-político daquela época como algo construído a partir de relações assimétricas e instáveis baseadas no conflito e na negociação entre diversos atores sociais. Identidades coletivas que ganharam forma através de conflitos pautados pela distribuição desigual de bens materiais e simbólicos, vale reforçar esse aspecto. Desse modo, foi definitivamente abandonada qualquer alusão a noções de identidade transcendentes e anacrônicas que permearam as ideias dos teóricos do populismo até os anos 1970. Essa reinterpretação crítica do período populista deixou claro também que

19 Para melhor compreensão sobre o tema na atualidade, ver: Fortes e French (2013). 
havia uma complexidade no mundo social que não podia ser plenamente capturada por uma leitura dura que apenas reproduzia a oposição hegemônica entre capital e trabalho. Por conseguinte, a sociologia da ausência (das classes e do povo, em geral) passou a ser substituída pela historiografia da formação dos sujeitos. Sendo assim, termos como heteronomia, passividade, irracionalidade e manipulação foram erradicados do vocabulário que visava definir as classes trabalhadoras brasileiras durante a experiência democrática da República de 46. No entanto, a superação dos paradigmas estruturalistas e funcionalistas passou a dar lugar a uma enorme multiplicidade de formas de construção das identidades sociais, o que acarretou em certa dificuldade para encontrar, no meio dessa fragmentação, um sentido mais adequado para o termo populismo. Na verdade, a geração de historiadores se preocupou em definir o processo de formação das classes trabalhadoras e não propriamente o populismo. Isso levou estes pesquisadores a se concentrarem menos na construção e mais na desconstrução de um conceito que se colocava como um obstáculo epistemológico para a empreitada com a qual se comprometeram. Em todo caso, o período populista passou a ser compreendido através de uma dinâmica própria de construção da democracia e da cidadania e não mais como algo que levava a deterioração dessas categorias.

\section{O populismo no Luta Democrática: uma abordagem alternativa}

O espaço político numa democracia não é composto apenas por identidades em formação, mas, antes disso, por demandas em formação. Muitas dessas demandas não são nem sequer atreladas a grupos sociais específicos e muito menos ainda a atores sociais engajados. Sendo assim, cabe questionar como seria possível analisá-las para entender o processo de construção do político em uma sociedade. A principal inovação das ideias de Laclau (2013) é justamente considerar as demandas democráticas da "plebs" como ponto fulcral para a construção da lógica populista. Essas demandas são expressas como reivindicações a certa ordem estabelecida. Todavia, o conjunto dessas demandas numa sociedade democrática é sempre incomensurável e bastante variado, porém, elas possuem um ponto de equivalência definido justamente por se dirigirem às instituições ou grupos que podem vetar ou viabilizar a sua realização. Ou seja, a 
equivalência não se refere a uma ideologia comum, a ideias comuns ou a uma cultura comum, mas ao próprio antagonismo.

Contudo, não é apenas esse antagonismo que define a lógica populista. Na primeira parte deste artigo expliquei que o discurso é o meio através do qual esse antagonismo entre o "povo" e o bloco de poder se expressa. Nesse sentido, as práticas discursivas constroem o objeto totalizador das demandas democráticas (o "populus"), e podem ser consubstanciadas no nome do líder político através de uma catacrese. Esse processo se dá no âmbito do discurso popular por meio da produção do que o autor chama de "significantes vazios". Esse termo serve para designar o discurso popular vago e impreciso que exerce a tarefa simbólica fundamental de sintetizar a experiência populista. Nesse caso, a vagueza ou a imprecisão do discurso popular não são consideradas como adjetivos pejorativos (conforme definiram as primeiras teses sobre o populismo no Brasil), mas sim como uma racionalidade estratégica composta por elementos retóricos essenciais para a compreensão do político. Ou seja, o discurso popular não é concebido como um estágio anterior de um discurso político maduro e pautado por um alto nível de deliberação ideológica ou institucional.

Feitas essas considerações sobre a "razão populista", cabe agora demonstrar como o discurso popular e a nomeação do líder que lhe dá unidade, estão presentes nas páginas do jornal Luta Democrática. Por ter sido um veículo de comunicação de massa de significativa penetração na população do estado do Rio de Janeiro, é crucial analisar o espaço que esse jornal dispôs para as reivindicações sociais. A pesquisa sobre o discurso popular presente neste periódico é importante para entendermos melhor os caminhos pelos quais enveredaram as formas de participação política durante a experiência democrática da República de 46. A partir dessa análise foi possível revelar noções de pertencimento e mostrar modos de construção de demandas populares normalmente incapazes de serem evidenciados apenas através de fontes produzidas por vias institucionais formais ou mesmo em pesquisas que se dedicam exclusivamente aos discursos produzidos no interior de certos grupos sociais.

O Luta Democrática seguia o padrão de produção dos grandes jornais da época, exibindo manchetes sensacionalistas, com forte apelo emocional. Porém, tinha uma peculiaridade em relação aos outros jornais populares, haja vista que não só circulava na capital da República, como também no interior do estado do Rio de Janeiro e, 
principalmente, nos municípios da Baixada Fluminense. Em razão dessa característica, o periódico possuía várias colunas e seções voltadas para esta região. Mas, essa não era a única particularidade do Luta Democrática. Por transitar entre a capital e as regiões em seu entorno, o jornal foi fundamental para consolidar uma das principais marcas do fenômeno político expressado por Tenório Cavalcanti ao longo dos anos 1950 e 1960: a capacidade de construir um canal simbólico de comunicação que ligava a periferia ao centro. Isso significa dizer que, naquele momento, o deputado fluminense tentava se colocar como um representante popular capaz de expressar, através de seu jornal, a voz da periferia e trazê-la para o centro do debate político, até então consolidado na capital da República.

Entre 1954 e 1960, o Luta Democrática expressou certo alinhamento às principais ideias do maior partido de oposição na época - a UDN - partido ao qual Tenório Cavalcanti foi filiado durante esse período. Houve claramente uma tentativa consciente de popularizar um partido tradicionalmente considerado elitista e disputar espaço com políticos populares de outros partidos, principalmente do PTB. Em 1960, rixas partidárias fizeram com que o político de Caxias saísse da UDN e se tornasse uma liderança de pequenos partidos alinhados ao trabalhismo. Entre 1960 e 1964, o jornal deu uma guinada radical e passou a identificar Tenório Cavalcanti como um herdeiro do trabalhismo varguista. No entanto, cabe ressaltar que a transformação do alinhamento ideológico do jornal dentro do campo político nacional não alterou a construção do discurso popular em torno do qual se construiu a legitimidade política do parlamentar fluminense.

\section{Os discursos sobre os direitos trabalhistas}

Diversas categorias profissionais foram representadas nas páginas do Luta Democrática. O periódico destinou muitas colunas e notícias voltadas para as reivindicações sobre direitos trabalhistas. Com publicação cotidiana, a coluna Consultório Trabalhista: conheça seu direito ${ }^{20}$ tinha como objetivo explicar, de forma didática, esses direitos e responder dúvidas enviadas pelos leitores sobre questões trabalhistas. As respostas sempre mencionavam os artigos da Consolidação das Leis do Trabalho (CLT) a fim de aconselhar os trabalhadores como agir em diversas situações. Essas colunas indicam que

20 A coluna foi publicada apenas nos primeiros meses de circulação do jornal. Junto com ela o seu autor também publicava a coluna Justiça do Trabalho, cujo conteúdo era o mesmo. Ao lado dessas colunas havia também a seção Pautas de Hoje, anunciando ações em litígio na justiça do trabalho. 
mesmo um jornal que se inseria claramente no campo oposicionista, não podia abrir mão de dedicar um bom espaço para questões relacionadas aos direitos trabalhistas se quisesse ser popular. Não se tratava, obviamente, de uma submissão involuntária à força política de Getúlio Vargas e do PTB, mas sim de uma sensibilidade para operar uma linguagem que se tornava comum às classes trabalhadoras brasileiras. As colunas mostravam operários dispostos a conhecer a legislação trabalhista para negociar com os patrões e defender seus direitos. Não eram, portanto, operários passivos, esperando serem protegidos pela lei. Muitas eram as questões colocadas pelos leitores. Num certo dia, por exemplo, o pintor Joaquim de Souza, após explicar os termos de seu acordo de trabalho com uma empresa construtora de imóveis, perguntou se o seu contrato era por tempo determinado ou indeterminado e quais os direitos que Ihe caberiam caso fosse despedido injustamente. Como de praxe, a resposta indicava o artigo da CLT referente ao caso (LUTA DEMOCRÁTICA, 17/2/1954, p. 6).

A oposição explorou amplamente as notícias sobre problemas sociais e greves como forma de alardear a crise política e econômica que se desenrolou ao longo do ano de 1954. No entanto, o jornal de Tenório Cavalcanti não utilizou este artifício para atacar o projeto trabalhista, mas para reforçar a necessidade urgente de sua ampliação através de um governo que deveria ser mais correto e menos corrupto do que aquele que estava no poder. Logo em sua primeira edição, o periódico marcou esta posição ao publicar a manchete: A mulher trabalha mais de oito horas diárias! O Ministério do Trabalho estará a par das irregularidades? A reportagem subsequente expressou:

A Divisão de Higiene e Segurança do Trabalho a quem esta afeta a fiscalização do trabalho da mulher, vem de há muito permitindo que comerciantes e industriais desta capital prorroguem o trabalho de suas empregadas e operárias por mais de oito horas diárias, dispensando a apresentação do acordo coletivo assinado entre as partes [...] e não exigindo que as mesmas sejam submetidas a exame médico, conforme determina clara e taxativamente a Consolidação das Leis do Trabalho [...] A nosso vê, tal decisão fere frontalmente a lei e se opõe aos interesses dos trabalhadores. (LUTA DEMOCRÁTICA, 3/2/1954, p. 6).

Foram várias as convocações de greves e assembleias anunciadas pelo Luta Democrática ao longo do ano de 1954. Diversas categorias expuseram nas páginas do periódico as suas reivindicações. A maioria delas pedia o cumprimento da legislação 
trabalhista e o reajustamento salarial referente à decisão do governo tomada em 10 de maio, que decretou o aumento do salário mínimo em 100\%. Essas notícias não apresentavam uma sociedade civil apática e engessada por um Estado fortemente regulador. Tampouco, parecia haver uma espécie de "acordão" policlassista capaz de dar uma solução aparente aos problemas do mundo do trabalho. Se a questão sobre a criação de um movimento autônomo não se colocava para os trabalhadores da época, como sugeria a pauta dos teóricos do populismo dos anos 1960 e 1970, não era por falta de consciência de classe, mas pelo simples fato de que se o Estado existia, enquanto personagem político apto a negociar, ele deveria ser colocado em cena, mesmo que fosse para criticá-lo.

A notícia sobre uma greve dos trabalhadores da indústria de massas alimentícias, acompanhada pelo Luta Democrática durante alguns dias, pode evidenciar estas questões. Waldemiro Luiz da Silva, presidente do sindicato da categoria, assim declarou ao jornal a respeito da greve decidida em assembleia:"Não estamos pedindo os moinhos dos patrões, mas apenas um aumento de salários para não morrermos de fome" (LUTA DEMOCRÁTICA, 5/2/1954, p. 3). O movimento grevista seria viabilizado através de um pacto firmado entre os trabalhadores em massas alimentícias e os da indústria do açúcar para defesa de interesses comuns. Por intermédio de Waldemiro, os trabalhadores também registraram no jornal uma crítica à inoperância da Federação de Alimentação, haja vista que o seu presidente, Antônio Guimarães, teria se tornado inimigo dos trabalhadores após assumir o cargo de presidente do Tribunal do Trabalho, órgão destinado a administrar os impasses entre patrões e empregados. Prossegue a reportagem mostrando a organização do movimento, que criou uma comissão de piquetes para coordenar os trabalhadores nas fábricas, e divulgando que os grevistas comunicaram às autoridades a decisão tomada pela assembleia a fim de que o movimento não fosse declarado inconstitucional. Dois dias depois, o jornal anunciou a data da greve e reforçou que as negociações com os patrões e com o Estado não progrediram. A manchete assim relatou a decisão: A zero hora de amanhã a greve do trigo. Os operários recusaram a proposta de adiamento da parede. A notícia seguiu mostrando mais uma declaração do presidente do sindicato: "Se os patrões não recuarem na intransigência iremos à greve à zero hora do dia 8. Não é possível esperar mais" (LUTA DEMOCRÁTICA, 7/2/1954, p. 1). A participação do Estado nas negociações foi narrada da seguinte forma: 
O Ministério do Trabalho esperava conseguir mais um adiamento do caso, tendo o Sr. Gilberto Cockratt de Sá apresentado uma proposta nesse sentido aos trabalhadores na mesa redonda realizada no Departamento Nacional do Trabalho (DNT), que foi recusada unanimemente. (LUTA DEMOCRÁTICA, 1954).

É claro que interessava ao Luta Democrática jogar contra o Ministério do Trabalho, já que o jornal se inseria no campo oposicionista. Contudo, mesmo descrevendo o governo como autoritário e coercitivo, o periódico mostrava um movimento operário atuante e consciente de seus interesses. Em todo caso, o Ministério do Trabalho, fundamentalmente através de seu órgão mediador - o DNT - teve ampla participação e foi bastante chamado naquele ano para resolver os conflitos entre empregados e empregadores, nem sempre com êxito. Um bom exemplo deste cenário de negociações foi relatado na cobertura da greve dos trabalhadores dos bondes da capital durante o segundo semestre de 1954. O jornal deu ampla cobertura ao desenrolar dos conflitos entre os empregados e os proprietários da Light, a concessionária que administrava o serviço público. Em nota, o Sindicato dos Trabalhadores em empresas de carris urbanos se pronunciou contra a postura patronal da Light:

[...] Durante toda a discussão das reivindicações trabalhistas promovidas por este sindicato ficou evidenciado seu espírito de concórdia e transigência, assim como a de todos os trabalhadores que representa. Além de diminuírem a sua pretensão inicial, aceitaram a proposta conciliatória apresentada pelo Diretor do Departamento Nacional do Trabalho, depois de terem concedido todos os prazos que foram solicitados. Enquanto assim procediam os trabalhadores, a empresa a tudo se negou para conciliar [...] pois a ela, Light, só interessa uma coisa, aumentar o preço das passagens [...] toda crise que culminou com a suspensão da assembleia sindical pela Polícia Civil e, consequentemente, condução direta dos trabalhadores para a chefatura de polícia foi motivada simplesmente pelo fato dos trabalhadores não concordarem em condicionar os novos salários a aumento de tarifa. [...] O apelo dirigido ao patriotismo e ao espírito ordeiro dos trabalhadores deveria ser encaminhado a Light [...] Os trabalhadores em carris urbanos reafirmam que o atendimento de suas justas e legais reivindicações pode e deve ser realizado sem aumento tarifário, ficando esclarecido que a ação governamental - inclusive a da Polícia Civil - deve ser concentrada na empresa. (LUTA DEMOCRÁTICA, 26/9/1954, p. 2).

Todo momento de crise, como foi o final do segundo governo Vargas, é mais propício a tensões sociais. Contudo, as notícias sobre greves, conflitos e negociações envolvendo empregados, empregadores e o Ministério do Trabalho, assim como o 
espaço aberto às reivindicações trabalhistas continuaram presentes no Luta Democrática durante o todo período democrático. Em fins de 1958, Waldir José Mansure, repórter do Luta Democrática - que foi candidato a vereador pela UDN do Distrito Federal no pleito de outubro daquele ano - passou a escrever a coluna Ronda Sindical. A coluna se pautava, sobretudo, pelo anúncio de greves, mesas-redondas, reuniões e assembleias de trabalhadores, enfatizando sempre os motivos de suas reivindicações ${ }^{21}$. Em 1960, esta coluna passou a se chamar Luta Sindical e, posteriormente, o genro de Tenório Cavalcanti, Humberto Francesconi, assumiu a função, mudando o nome da coluna para Movimento Sindical. Nessas publicações as notícias envolviam ameaças de greves caso os patrões não cumprissem a lei, disputas travadas no Tribunal Regional do Trabalho, exigências por reajuste salarial, reivindicações para a obtenção de contrato coletivo de trabalho, dentre outras questões²2. Ainda na década de 1960, Tenório Cavalcanti levou ao ar a Rádio Difusora de Caxias. O político e líder sindical Waldemar Viana, eleito deputado estadual pela Guanabara nas eleições de 1960, tinha um programa nessa rádio. Mais tarde, o colunista Humberto Filho passou a publicar no jornal informações sobre o programa de Waldemar Viana. Durante a campanha eleitoral de 1962, Humberto Filho assim escreveu:

Lembramos aos companheiros que esta coluna e o programa sindical e trabalhista, realizado todas as quartas, às 20 horas, na Rádio Difusora de Duque de Caxias (da Organização Tenório Cavalcanti), continua à inteira disposição dos trabalhadores e dirigentes sindicais para quaisquer denúncias contra os que desrespeitam as leis trabalhistas. Portanto, não vacile, venha denunciar os infratores para o seu próprio benefício. As portas continuam abertas na "Emissora da Liberdade." (Luta Democrática, 12/9/1962, p. 5).

O que se percebe nessas notícias e colunas é que havia trabalhadores razoavelmente organizados, conscientes de seus direitos e aptos a negociar. Assim, eram críticos aos patrões e ao papel desempenhado pelas instituições que representavam o Estado na defesa dos trabalhadores. Nestes casos, o Estado não era entendido como uma entidade paternalista, cuja função era proteger sindicatos frágeis e incapazes de agir contra os patrões. Portanto, por mais que a estrutura política da época colocasse o Estado

21 No início dos anos 1960 também foi criada a coluna intitulada Sindicalismo no Estado do Rio, de Irene Wanderley.

22 As questões referentes aos direitos dos aposentados e pensionistas da previdência social também ganharam destaque nas páginas do Luta Democrática. Em 1960, o general Jaime Ferreira, presidente do Comitê Nacional de Defesa da Previdência Social, passou a escrever a coluna chamada: Bom dia, trabalhador, onde abordava os direitos, reivindicações, conquistas e necessidades da classe. 
exercendo uma função de suporte para os trabalhadores e para os sindicatos, estes não apresentavam um discurso submisso a ele. Mesmo porque esta função do Estado, na prática, não necessariamente ajudava a consolidar a ação coletiva dos sindicatos e, às vezes, favorecia a classe patronal. Dessa forma, o Estado era também pressionado pelos trabalhadores ou para sair de uma negociação ou para entrar nela.

\section{As queixas sobre a ocupação do espaço na sociedade}

As seções dedicadas às reclamações do público leitor foram uma das principais ferramentas de intermediação utilizadas pelos jornais de massa a fim de criar vínculos entre as lideranças políticas e a população. Desde o seu primeiro ano de circulação, o Luta Democrática buscou se identificar com o público leitor que desejava atingir, ou seja, a população mais pobre. As colunas, manchetes e notícias do jornal se dedicaram a denunciar variados tipos de problemas e demandas sociais, sempre destacando o antagonismo entre os mais despossuídos (de direitos, poder ou riqueza) e as elites. Algumas colunas foram destinadas para as queixas dos leitores e outras publicaram as ideias de colunistas sobre temáticas relativas à cidade e os espaços ao seu redor. Nos seus primeiros meses de circulação, o jornal criou as colunas Como Pensa o Leitor e Tribuna do Leitor, esta última editada por Saldanha Marinho. Nessas colunas, eram expostas reclamações sobre problemas dos mais variados tipos, mas, em geral, dedicadas a ocupação do espaço na sociedade. A coluna intitulada As lamúrias do velho Napoleão, expôs as queixas de um tenente aposentado sobre o abuso realizado pelos donos de pequenas hospedarias do centro da cidade do Rio de Janeiro, que cobravam caro e ofereciam maus serviços para a grande quantidade de habitantes da capital que, usualmente, procuravam esses lugares para dormir. A reclamação do leitor foi exposta desse modo:

O sono dos párias e dos solitários mal assalariados desta mimosa cidade do Rio de Janeiro está hoje também sendo objeto da mais vil exploração, monopólio que é - por mais incrível que pareça - de um grupo de comerciantes inescrupulosos que vive à margem do comércio hoteleiro, desfrutando a indústria das hospedarias mais vulgarmente chamadas "biroscas", espalhadas por todo centro urbano. Essa grave queixa contra a situação de calamidade econômica que atravessamos foi-nos relatada pelo velho pernambucano, Napoleão de Souza Velho [...] que conhece a fundo a vida pobre da nossa cidade. Antigamente - disse-nos ele - havia na rua da Misericórdia uma hospedaria que alugava "corda" para 
dormir a 300 réis. Era o seguinte: havia um banco muito comprido, encostado à parede em que o hóspede se sentava, tendo a frente uma corda e, debruçado, dormia até às seis horas da manhã, quando o espanhol retirava a corda do gancho e todos caíam se não estivessem prevenidos. Havia uma fila de bancos no salão e, alta noite, ficavam todos lotados. Na"corda" dormiam indivíduos os mais diferentes, inclusive boêmios da Lapa que perdiam dinheiro no jogo ou que eram depenados por mulheres vadias. A polícia quase sempre fazia boa safra de ladrões que apanhava na "corda" (LUTA DEMOCRÁTICA, 23/2/1954, p. 3).

Após a narrativa sobre a antiga hospedaria, Napoleão rogou o seu protesto pela imprensa. Criticou os comerciantes espanhóis que dominavam o ramo das "biroscas" e o descaso dos fiscais da Prefeitura:

Os espanhóis das "biroscas"são, em geral, caguetes da polícia e entregam ladrões que dormem tranquilamente, intrujões e tudo, embora, também sejam useiros e vezeiros em comprar roubos. Cobram vinte e cinco cruzeiros por uma cama no salão com toda a sujeira de percevejos e lençóis que só mudam de semana em semana, para todos os hóspedes, mesmo que o do dia não seja o mesmo da véspera. [...] Veja só, um pobre diabo como eu pago por uma cama suja, cheia de percevejos, num salão de "birosca" tanto quanto um "barnabé" milionário letra "O" da prefeitura num hotel fiscalizado de classe. (LUTA DEMOCRÁTICA, 23/2/1954, p. 3).

As colunas e as seções dedicadas às queixas da população sobre a vida urbana ocuparam um bom espaço no Luta Democrática. Merece destaque as seções abertas aos problemas relacionados às regiões periféricas da cidade e aos municípios do interior do estado do Rio de Janeiro, menos falados do que a capital nos grandes jornais da época. Ainda em suas primeiras edições o jornal criou a seção Notícias Fluminenses, com uma página inteira dedicada às cidades da região. Duque de Caxias e os demais municípios da Baixada Fluminense ganharam atenção especial, embora a seção procurasse abordar, dentro do possível, aspectos de todas as cidades do estado do Rio de Janeiro. Nessa coluna havia inúmeras denúncias sobre o mau funcionamento dos serviços públicos e problemas urbanos, como aqueles relacionados aos transportes públicos, calçamento e iluminação de ruas, saneamento básico - principalmente o problema da falta d'água -, saúde, educação e muitas informações sobre crimes, acidentes e tragédias naturais. Normalmente, ao relatar os problemas dos municípios, o jornal também cobrava 
atitudes das autoridades. Numa das seções, a cidade de São João de Meriti, pertencente a Baixada Fluminense, foi relatada da seguinte forma:

Município de setenta e seis mil habitantes, São João de Meriti sofre com absoluta falta de higiene e descaso sanitário. Aqui não há esgoto nem água encanada. A frente das residências há valetas onde toda sorte de detritos se acumulam e apodrecem [...] A luz de Meriti é adquirida da Light porque o Estado não Ihe ajuda em nenhum sentido. A população cresce constantemente sem nenhum amparo das autoridades locais. (LUTA DEMOCRÁTICA, 23/2/1954, p. 2).

A seção Notícias Fluminenses teve vida curta, porém, o espaço aberto aos municípios do estado continuou existindo no jornal. Surgiram outros nomes, como Municípios Fluminenses e Do outro lado da Baía, mas a temática continuou a mesma. Além das queixas individuais, também era comum o jornal relatar a ida de comissões de moradores de um determinado local para fazer reclamações.

A ocupação do espaço urbano e rural entre os anos 1950 e 1960 do século XX foi extremamente problemática no Brasil. Neste período, enormes contingentes populacionais, provenientes principalmente do Nordeste do país, migraram para o Rio de Janeiro sem que houvesse políticas públicas eficazes com o objetivo de alocar adequadamente esta população. Como resultado, surgiram diversos conflitos relacionados à questão da terra, que se espalharam desde as favelas da capital, passando pelo chamado Sertão Carioca²3, a Baixada Fluminense, chegando até às regiões mais periféricas do estado. Denúncias sobre a atividade de grilagem ocuparam as páginas do Luta Democrática durante todo o período aqui analisado. Normalmente eram noticiadas disputas entre os grileiros, mancomunados com os poderes públicos e amparados pela polícia, contra os posseiros. A seção Municípios Fluminenses trouxe a seguinte manchete sobre o município de Duque de Caxias: Desmoralizada a justiça de Caxias. A reportagem subsequente assim expôs: "Os grileiros no município de Caxias gozam de imunidades inconcebíveis e usam a polícia a seu talante em violenta perseguição a legítimos posseiros, que lavraram a terra há mais de 15 anos." (LUTA DEMOCRÁTICA, 24/2/1954, p. 2). A notícia relatou que uma comissão

23 A área que ficou conhecida como Sertão Carioca englobava os bairros que hoje pertencem à Zona Oeste da cidade do Rio de Janeiro. O termo se referia, especialmente, aos bairros de Campo Grande, Realengo, Santa Cruz, Guaratiba e Jacarepaguá, que ficaram conhecidos pela sua caracterização mais rural do que urbana e pela semelhança com o modo de vida da população do Sertão Nordestino. Tal designação pode ser encontrada não apenas na imprensa como também em diversas obras literárias desde a década de 1930 do século XX. Segundo Sarmento (1998), o naturalista Magalhães Corrêa usou este termo pela primeira vez em crônicas publicadas no jornal Correio da Manhã entre 1931 e 1932. 
formada por nove lavradores foi à redação do jornal para esclarecer um conflito com grileiros. O relato revela que cerca de cento e cinquenta lavradores ocupavam, com as suas famílias, a região onde se encontrava a fazenda do Pilar, em terras pertencentes ao proprietário com o sugestivo nome de Américo Vespúcio. Prossegue a reportagem dizendo que os lavradores registraram uma Associação no cartório de Caxias a fim de fortalecer e legitimar a disputa, que já se estendia na justiça com acusações sobre os grileiros e sobre os policiais envolvidos em ações de despejo.

Porém, as disputas por terras não ocorriam apenas nas zonas mais afastadas do centro urbano. Estes conflitos também eram bastante comuns nas favelas da capital. A manchete: A Câmara Municipal desapropriou o morro da União, narrou a alegria dos moradores que foram à Câmara Municipal do Rio de Janeiro comemorar a votação favorável em relação ao projeto de lei sobre a desapropriação da referida localidade. (LUTA DEMOCRÁTICA, 3/7/1954, p. 3). Os problemas e demandas das favelas estiveram presentes nas páginas do Luta Democrática durante todo o período que constituiu essa pesquisa. Os moradores de favelas da cidade do Rio de Janeiro também costumavam ir à redação do Luta Democrática para denunciar diversos problemas relacionados à saúde, ao saneamento básico, aos transportes, à educação, à iluminação e ao calçamento de ruas. Em 1960, as favelas se tornaram um dos principais temas do debate político nas eleições para o estado da Guanabara, sendo Tenório Cavalcanti um dos candidatos nesse pleito. Todos os candidatos apresentaram soluções para os problemas sociais das favelas. Nesse ano, o Luta Democrática ampliou ainda mais o espaço para tratar do assunto. Como exemplo, pode-se citar a coluna Favelas, escrita por Naldir Laranjeiras ${ }^{24}$, candidato a deputado do estado da Guanabara pelo Partido Republicano (PR). Nessa coluna, o político apresentava soluções para os problemas dessas localidades no campo do trabalho, da habitação, da saúde e da educação.

\section{A retórica da defesa do consumidor, da justiça criminal e do direito ao voto}

Outros temas contribuíram enormemente para a popularização do Luta Democrática, de modo que várias formas de expressão da cidadania puderam ser representadas no jornal. O tema da defesa do consumidor, muito comum em programas jornalísticos de

24 Nas eleições de 1960, Naldir Laranjeiras se elegeu deputado estadual, com 8.438 votos (SARMENTO, 2008, p. 94). 
grande audiência até os dias atuais ${ }^{25}$, também tinha amplo espaço no jornal. Em fins de 1951, o governo Vargas, através do Ministério do Trabalho, Indústria e Comércio, criou a Comissão Federal de Abastecimento e Preços (COFAP). A esta instituição foi designada a tarefa de assegurar a livre distribuição de mercadorias e serviços essenciais ao consumo da população, sempre que deles houvesse carência. A COFAP se comprometia a fiscalizar os estabelecimentos comerciais e a tabelar os preços máximos dos revendedores, visando controlar o abastecimento de mercadorias e serviços em todo o país. Por ter esta função, a COFAP passou a ser uma espécie de órgão de defesa do consumidor e, portanto, respondia pelos interesses desse segmento. Em seu primeiro ano de circulação, O Luta Democrática não poupou críticas ao funcionamento desse órgão. O jornal denunciou os aumentos de preços e acusou a COFAP de não zelar pelos consumidores. As críticas se espalharam pelas diversas seções do periódico. A seção Municípios Fluminenses, assim denunciou no espaço dedicado ao município de Nilópolis:

Este jovem florescente município continua lutando contra sérios problemas que até hoje não tiveram solução. Assim é que seus habitantes são vítimas de toda sorte de explorações da parte de alguns comerciantes desonestos. Aqui não existe tabelamento de preços. A famigerada COFAP só existe na imaginação. Por aqui nunca passou a fiscalização da tal COFAP. Os preços são extorsivos. Os gêneros são da pior qualidade. (LUTA DEMOCRÁTICA, 24/2/1954, p. 2).

Tema também muito comum nos noticiários jornalísticos sensacionalistas é o da violência e do crime. Três colunas foram dedicadas a esse tema no jornal Luta Democrática. Logo em 1954, o advogado criminal e redator-chefe do periódico, Hugo Baldessarini, elaborou a coluna Retrato do Crime. O autor se pronunciou dessa forma a fim de explicar o seu objetivo:

Luta Democrática é um jornal de combate, que tem por objetivo criticar de forma construtiva tudo que representa erro, abuso ou violência. No setor criminal, como dissemos no primeiro número, recusamo-nos fazer a propaganda do crime e a apologia do criminoso, não querendo dizer com isso que pretendemos exaltar o agente da lei, que seja da polícia ou da justiça [...] Fiel a essa posição, procuraremos analisar o crime, técnica, científica e psicologicamente, situando crime e criminoso no seu meio peculiar [...] Por outro lado,

250 Deputado Federal Celso Russomanno, por exemplo, ganhou fama, durante os anos 1990, como repórter televisivo especializado na defesa do consumidor. 
manteremos, diariamente, uma coluna destinada a atender a consultas sobre qualquer assunto relativo à polícia e à justiça criminal, prontificando-nos a atender profissionalmente àqueles que sejam vítimas de algumas injustiças, fornecendo graciosamente o serviço dos nossos advogados. Podem, pois, consultar-nos por escrito ou profissionalmente que a todos atenderemos. (LUTA DEMOCRÁTICA, 5/2/1954, p. 3).

O jornal Luta Democrática ganhou fama por causa de suas manchetes e notícias sobre crimes bárbaros, anunciados, às vezes, num teor tragicômico: "Assassinado pela esposa quando estrangulava o sogro."(LUTA DEMOCRÁTICA, 14/10/1960, p. 1)."Português, querendo livrar-se da mulher, tentou enforcar-se com a gravata na delegacia." (LUTA DEMOCRÁTICA, 1/9/1955, p. 3). Assim, não deixa de ser curioso que Hugo Baldessarini recusasse, em sua coluna, "fazer a propaganda do crime e a apologia do criminoso". No entanto, é preciso levar em conta que o estilo sensacionalista dessas manchetes tinha a intenção de provocar no leitor uma noção de autorreconhecimento, ou seja, de que aqueles fatos faziam parte de sua própria realidade, não sendo, ao contrário, uma distorção dela. Desse modo, é possível entender que uma coluna cuja intenção era a de corrigir o crime e dar assistência aos supostos criminosos injustamente acusados, vinha bem a calhar.

A coluna Aspectos judiciários e policiais do estado do Rio de Janeiro também possuía um caráter mais formal e didático, porém, se voltava exclusivamente para o comportamento da polícia. Um dos números dessa coluna explicou o que caracterizava o abuso de autoridade policial (LUTA DEMOCRÁTICA, 2/7/1959). Outro número resolveu aconselhar os policiais a não consumirem bebidas alcoólicas durante o horário de trabalho (LUTA DEMOCRÁTICA, 8/7/1959, p. 3). Já a coluna Justiça sem toga, escrita por Bruzzi de Mendonça, ex-deputado federal pelo Partido Rural Trabalhista (PRT), procurava mostrar uma didática diferente. Essa coluna contava, através de relatos sobre a vida cotidiana, como os cidadãos e as autoridades interpretavam as leis e a justiça de acordo com diferentes padrões morais. O colunista costumava destacar que a legislação criminal tinha um peso determinado para os mais pobres e outro, bem diferente, para os mais abastados. Em uma das edições de sua coluna o deputado federal descreveu a história de Severino: 
Severino é um infeliz. Morava num barraco de favela na jurisdição do $24^{\circ}$ Distrito Policial. Um dia um senhorio resolveu cortar a luz do barraco no peito e na raça. Assim fez. Quando o Severino chegou em casa e soube do ocorrido, brigou com a mulher:- 'Como é que você deixou ele entrar? Você não sabe que a Constituição assegura a inviolabilidade do domicílio?' Para dar maior ênfase à lição de Direito Constitucional, Severino andou dando uns empurrões na esposa. Foi aí que entrou em cena a polícia para resolver a questão. O Severino exultou: -'Agora é que a polícia vai processar meu senhorio por crime contra a economia popular. Onde já se viu cortar a luz de um inquilino que está em dia?'Mas, que nada! A polícia processou o Severino por lesões corporais contra a sua mulher e ainda apreendeu uma bicicleta que ele tinha para passear aos domingos, como qualquer bacana. O nosso amigo ficou desconfiado que a polícia não gostava dele e veio pedir proteção ao Tenório. Este encaminhou-o ao ministro Falcão para que ele exigisse das autoridades policiais mais respeito às garantias do cidadão. Vai daí que o Severino chegou para o senhorio eufórico: - 'Olha, agora o negócio é diferente. O ministro da justiça está do meu lado. Daqui só saio se for indenizado.' O leso senhorio nada disse, nem Ihe foi perguntado. Foi saindo e voltou de noite em companhia de vários tiras. Um deles, que se intitulou comissário no 240 DP, depois de tentar convencer o Severino, chamou a mulher deste e foi dizendo: - 'Olha aqui, minha velha. Teu marido não tem juízo e vai se dar mal. Mas a senhora ainda pode se sair bem. Toma um conto de réis e larga ele. Vai procurar onde morar com as crianças porque ele nós vamos despejar à galega. A mulher pensou, pegou o dinheiro e foi embora... É para vocês verem, a polícia, em vez de prender ladrão, agora está fazendo desquites! (LUTA DEMOCRÁTICA, 13/5/1960, p. 3).

Severino procurou primeiramente se amparar na lei para resolver o seu caso. Porém, percebeu que a polícia, ao invés de ajudá-lo, o perseguia. A polícia não fazia isso pelo crime cometido contra a sua esposa, mas pelo fato do proprietário do barraco onde morava ser um "protegido" desta instituição. Então, Severino resolveu apelar para as autoridades que supunha estarem acima da polícia. Neste caso, esta autoridade era Tenório Cavalcanti, que o levou ao ministro da justiça. Segundo a interpretação de Severino, Tenório faria valer a lei a seu favor e, assim, a polícia Ihe daria proteção. Mas, ao que tudo indica, seu apelo não repercutiu e a polícia pôde continuar representando o lado até então considerado mais forte no conflito. A lei não esteve presente no desfecho do caso, mas ela serviu para que a polícia chegasse até Severino e o acusasse por um crime - o de lesão corporal contra a esposa - que provavelmente não teria importância 
para os policiais se não pudesse ser usado como pretexto para incriminar o cidadão. Ao fim e ao cabo, prevaleceu a máxima: "aos amigos tudo, aos inimigos a lei".

Em outra coluna, Bruzzi de Mendonça narrou mais um exemplo em que a lei, amparada por noções de moral, favoreceu o mais forte. O autor contou como foi o julgamento do caso de uma mulher acusada de assassinato:

As mulheres andam bárbaras. Antigamente eram os maridos que, por qualquer lesão à honra castigavam um paletó de madeira nas distintas. Mas, como dizia o saudoso Noel, no século do progresso o revólver teve ingresso para acabar com a valentia. O sexo fraco começou a matar e gostou. Daí vieram: Araci Abelha, Zulmira Galvão, etc. Até chegar aos recentes casos da 'louca da Penha' - sim, porque só loucura explica tanta selvageria da rádio-atriz que fez tiro ao alvo com o marido, fantasiada de homem - e da chamada 'virgem-assassinada'. Este último caso é que é gozado. Não se sabe porque uma certa imprensa tem protegido um bocado a moça. Só o apelido de virgem antes do exame já é uma defesa indireta, à qual não deve estar estranho o jovem e brilhante advogado Antônio Evaristo de Moraes Filho, o Evaristinho. Neste conto da juventude enganada pela vítima existem uma série de detalhes chatos, como por exemplo o dinheiro, o cheque, etc. Mas, deixa isso para lá, Zé! O gozado é o imparcial relatório feito pelo investigador encarregado de levantar a vida pregressa da moça. Diz coisas assim: 'A jovem foi durante todo tempo do depoimento assistida pelo conforto espiritual propiciado pela solidariedade materna, o que bem revela os sólidos laços afetivos que unem aquela família. Por outro lado, revelou uma firmeza de caráter e uma sensibilidade impressionantes nesse transe que Ihe perturbou a vida de adolescente...' Se não é exatamente isto, é quase isto. Agora, vocês imaginem um investigador com tais pendores literários fazendo o relatório do caso de um 'João da Silva' qualquer. A coisa iria sair mais ou menos assim: 'O acusado, durante todo o depoimento, pediu que Ihe deixassem falar com uma preta velha, que ele dizia ser a sua mãe. Provavelmente, o perigoso marginal, marcado pelos estigmas de todas as taras, queria solicitar-Ihe um dólar de maconha. Nem mesmo os paternais conselhos que o doutor delegado com o seu tradicional espírito evangélico Ihe propiciou, conseguiram afastá-lo de sua cínica negativa'. É diferente, não é? (LUTA DEMOCRÁTICA, 27/7/1960, p. 3).

A coluna descreveu que o pertencimento da ré a uma família de elite lhe garantiu reconhecimento perante a justiça. Assim, seu status de cidadã Ihe foi dado pela família a qual pertencia. Para o indivíduo pobre seria diferente. Ele seria, a princípio, desamparado, pertenceria a uma religião estigmatizada pelas instituições oficiais - controladas pela elite. A sua família, diversamente do que ocorria com o indivíduo da elite, não Ihe garantia 
um status de cidadão. Por isso, ele precisava que representantes do Estado fossem seu protetor e conselheiro.

Por fim, cabe destacar as informações prestadas pelo jornal em relação ao voto e ao processo eleitoral. Inúmeras denúncias de fraudes eleitorais foram expostas nas páginas do Luta Democrática. Próximo às eleições, o jornal costumava publicar instruções ensinando aos leitores como votar e como se portar na seção eleitoral. O processo eleitoral democrático era uma novidade para a sociedade brasileira da época. Em tempos de eleições, as cédulas comuns, distribuídas livremente, e os títulos eleitorais adquiriam um fortíssimo peso simbólico, sendo capazes de situar e identificar os cidadãos no mundo, assim como ocorria com a carteira de trabalho. Na véspera das eleições de 1954, o Luta Democrática estampou a manchete: O tarado não pôde ser preso porque tinha um título de eleitor. A reportagem subsequente relatou que um homem acusado de cometer abuso sexual contra uma criança, alegou na 27a DP, em Bangu, que de acordo com a lei não poderia ser preso, já que era eleitor. Em seguida, mostrou o seu título para o comissário de polícia (LUTA DEMOCRÁTICA, 2/10/1954, p. 1). Supostamente, o título de eleitor poderia Ihe conceder imunidades! Independente da veracidade ou não do caso, o enunciado evidenciou o peso simbólico do título eleitoral naquele contexto.

\section{Considerações finais}

O termo populismo foi amplamente incorporado na cultura política nacional, sobretudo, através dos meios de comunicação de massa durante os anos 1950 e início dos anos 1960 e, ao mesmo tempo, serviu como ferramenta analítica utilizada por alguns teóricos brasileiros para compreender as especificidades daquela conjuntura. Os significados desta categoria deslizam facilmente do campo das disputas políticas para o campo acadêmico, tornando-se, por vezes, um elo entre ambos. Constitui-se, assim, como uma ideia-força capaz de evidenciar as visões de mundo de uma época. De que forma podemos manejar as transformações dos significados do populismo ao longo da história para explicar a complexidade do político? Creio que esta seja a principal pergunta que se deve fazer ao tentar resgatar este termo. Na segunda parte deste artigo tomei como base as ideias de Laclau sobre o populismo e procurei mostrar o modo como foram se construindo noções de cidadania e de identidade coletiva a partir das demandas populares publicadas nas páginas do jornal Luta Democrática. A pesquisa 
colocou em destaque as manchetes, reportagens, seções e colunas dedicadas às queixas e reivindicações sociais, assim como, às ideias e interpretações dos colunistas (sendo que alguns deles eram políticos pertencentes à base aliada de Tenório Cavalcanti). Esse conjunto de discursos e opiniões, tornado público, revela não apenas a maneira como a população compreendia e usava a legislação trabalhista vigente na época, como também mostra o antagonismo entre as demandas de diversos segmentos sociais e as elites, fossem estas econômicas ou políticas (as instituições públicas). Ou seja, o jornal evidenciava o conflito entre o "povo" e o chamado bloco de poder naquele contexto.

Como resultado desta análise sobre os discursos populares que constituíam o Luta Democrática, foi possível revelar vestígios sobre a expressão da cultura popular de uma época, pois foram relatados valores, códigos morais e estratégias políticas que conformaram uma espécie de gramática política popular que, consequentemente, deu forma a uma identidade coletiva. Esta gramática ou discurso popular precisaram de um "significante vazio" que se cristalizou na imagem pública de Tenório Cavalcanti. O parlamentar fluminense não poderia construir esta imagem sem que o jornal funcionasse como um espaço público de mediação com a população. Muitas queixas pediam a intervenção direta de Tenório Cavalcanti junto aos órgãos públicos como uma forma de facilitar a resolução dos conflitos. É claro que isso explicita uma relação assimétrica da população com o líder político. Vale destacar, no entanto, que ao expor as diversas demandas sociais e criar uma ideia vaga de antagonismo político, o jornal contribuía para gerar formas de equivalência e de identidade entre o "povo" (entendido de modo totalizante) e o líder político (seu legítimo representante) ao mesmo tempo em que dava contornos mais definidos ao campo político no qual Tenório Cavalcanti estava inserido. Desse modo, o resultado da pesquisa nos leva a desvendar novas maneiras de interpretar identidades coletivas, formas de representação política, assim como, noções de cidadania e pertencimento. Pode também contribuir para abrir espaço para uma agenda de pesquisas sobre discursos populares e lideranças políticas, conferindo uma nova forma de abordagem a respeito da história política no Brasil.

\section{Referências}

CAPELATO, M. H. Mídia e populismo/populismo e mídia. Revista Contracampo, v. 28, n. 3, p. 52-72, 2013. 
CHALOUB, J. Os resquícios de 1946: populismo e udenismo no debate brasileiro contemporâneo. In: ENCONTRO ANUAL DA ANPOCS, GT 19: INTELECTUAIS, CULTURA E DEMOCRACIA, 38. 2014, Caxambu. São Paulo: ANPOCS, 2014.

COSTA, H. et al. (Ed.). Na luta por direitos: estudos recentes em História Social do Trabalho. Campinas: Editora da Unicamp, 1999.

FERREIRA, J. O nome e a coisa: o populismo na política brasileira. In: FERREIRA, J. (Ed.). O populismo e sua história: debate e crítica. Rio de Janeiro: Civilização Brasileira, 2001. p. 59-124.

FORTES, A.; FRENCH, J. D. Sobre encanadores e filósofos: fazendo história do trabalho no Brasil. In: FORTES, A. et al. (Ed.). Cruzando fronteiras: novos ol hares sobre a história do trabalho. São Paulo: Fundação Perseu Abramo, 2013. p. 17-28.

FRENCH, J. D. Afogados em leis: a CLT e a cultura política dos trabalhadores brasileiros. São Paulo: Fundação Perseu Abramo, 2001.

GOMES, A. C. O populismo e as ciências sociais no Brasil: notas sobre a trajetória de um conceito. Tempo, v. 1, n. 2, p. 31-58, 1996.

IANNI, O. O colapso do populismo no Brasil. Rio de Janeiro: Civilização Brasileira, 1968.

JAGUARIBE, H. Que éo Ademarismo? Rio de Janeiro: IBESP, 1954. p. 139-149. (Cadernos do nosso Tempo).

KOSELLECK, R. Futures Past: on the semantics of historical time. London: MIT Press, 1985.

LACLAU, E. A razão populsita. São Paulo: Três Estrelas, 2013.

LUTA DEMOCRÁTICA. Rio de Janeiro: Biblioteca Nacional, 1954.

LUTA DEMOCRÁTICA. Rio de Janeiro: Biblioteca Nacional, 1955.

LUTA DEMOCRÁTICA. Rio de Janeiro: Biblioteca Nacional, 1959.

LUTA DEMOCRÁTICA. Rio de Janeiro: Biblioteca Nacional, 1960.

LUTA DEMOCRÁTICA. Rio de Janeiro: Biblioteca Nacional, 1962.

MOISÉS, J. Á. Greve de massa e crise política: estudo da greve dos 300 mil em São Paulo (1953-1954). São Paulo. Polis, 1978.

NICOLAU, J. História do voto no Brasil. Rio de Janeiro: Jorge Zahar, 2004.

RAMOS, A. G. A crise do poder no Brasil. Rio de Janeiro: Civilização Brasileira, 1961.

RODRIGUES, L. M. Classe operária e sindicalismo no Brasil. In: RODRIGUES, L. M. (Ed.). Sindicalismo e Sociedade. São Paulo: Difusão Europeia do Livro, 1968.

SARMENTO, C. E. Pelas veredas da capital: Magalhães Corrêa e a invenção formal do sertão carioca. In: ENCONTRO REGIONAL DE HISTÓRIA, 7., 1998, Rio de Janeiro. Anais... Rio de Janeiro: ANPUH/RJ, 1998.

SARMENTO, C. E. O espelho partido da metrópole: Chagas Freitas e o campo político carioca (19501983), liderança, voto e estruturas clientelistas. Rio de Janeiro: Folha Seca/FAPERJ, 2008.

SIQUEIRA, C. V. Sexo, crime e sindicato: sensacionalismo e populismo nos jornais Última Hora, O Dia e Luta Democrática durante o segundo governo Vargas (1951-1954). Tese (Doutorado)Pontifícia Universidade Católica do Rio de Janeiro, Rio de Janeiro, 2002.

THOMPSON, E. P. A formação da classe operária inglesa. Rio de Janeiro: Paz e Terra, 1987.

WEFFORT, F. O populismo na política brasileira. Rio de Janeiro: Paz e Terra, 1978.

Recebido: 12 jan., 2017

Aceito: 20 abr., 2017

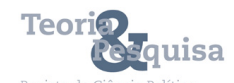

